\title{
Emergency Remote Teaching: Capturing Teacher Experiences in Spain with SELFIE
}

\author{
Laia Albó ${ }^{[0000-0002-7568-9178]}$, Marc Beardsley ${ }^{[0000-0002-3874-0739]}$, \\ Judit Martínez-Moreno ${ }^{[0000-0001-9234-8220]}$, Patricia Santos ${ }^{[0000-0002-7337-2388]}$, \\ Davinia Hernández-Leo ${ }^{[0000-0003-0548-7455]}$ \\ Universitat Pompeu Fabra, Barcelona, Spain \\ \{laia.albo, marc.beardsley, judit.martinez, patricia.santos, \\ davinia.hernandez-leo\} @upf.edu
}

\begin{abstract}
COVID-19 thrust teachers into emergency online pedagogy. Teachers had to rapidly digitize their practices. A week into compulsory online teaching, we captured a snapshot of teacher experiences to identify their impressions of support received and the challenges they faced in relation to teaching remotely. We conducted a survey study with primary and secondary school teachers in Spain. 67 teachers completed an adapted version of SELFIE to measure the way digital technologies are used for teaching. Respondents were directed to mark two responses to each survey item to reflect the situations both before and during the pandemic. Results indicate that during the pandemic teachers had more training opportunities, found online professional training to be of greater use, and gained confidence in using a wide variety of technologies for both teaching and communicating with parents and students. However, the digital divide among students and a lack of technical resources and support affected their abilities to carry out online education effectively. Our study highlights teachers' perspectives on the rapid advancement of digital competences and technology in education. Information that can inform TEL research and interventions.
\end{abstract}

Keywords: Emergency remote teaching, COVID-19, SELFIE, Digital skills, Teacher professional development.

\section{Introduction}

As a result of the COVID-19 outbreak, brick-and-mortar Spanish educational centres (all levels) were directed by the government to cancel face-to-face teaching around midMarch 2020. As social distancing measures were being prolonged, the government mandated that education had to continue remotely. This led educational centres and their teachers to hurriedly digitize their educational offerings. Consequently, teachers faced challenges in rapidly advancing their digital competences and tightly integrating technology into their practices. How this digitalization was done in the COVID-19 context and its implications is a relevant matter for Technology-Enhanced Learning (TEL) research. Some early voices reckon that the situation represented "emergency remote teaching" [1], and conceivably involved the suboptimal uses of TEL derived from improvised solutions by potentially poorly trained and stressed teachers. Yet, the forced 
adoption of digital technologies also presents an opportunity to explore the digital technologies, practices and training (professional development) that teachers have found to be useful in the current context - offering a potential foundation from which digital competences can be further advanced. In our study, we captured a snapshot of teacher experiences to identify their impressions of support received and the challenges they faced in relation to teaching remotely. The aim of our work is to highlight challenges teachers need support in facing with the rapid advancement of digital competences and technology in education.

\section{Digitalization of Education}

In 2018, the European Commission adopted a Digital Education Action Plan [2] aimed at preparing Europe for the forthcoming digital age. The plan's objectives included fostering technology use and digital competence development in education and focused on three priorities: (1) Making better use of digital technology for teaching and learning; (2) Developing digital competences and skills; (3) Improving education through better data analysis and foresight. In the same year, the Teaching and Learning International Survey (TALIS) was conducted. TALIS results [3] highlighted the need to support teachers in making use of information and communication technologies (ICT). Key findings were that "only $56 \%$ of teachers across the OECD participated in training in the use of ICT for teaching as part of their initial education or training," "only $43 \%$ of teachers felt well or very well prepared for this element when they began teaching," $25 \%$ of school leaders said that "inadequate use of digital technology for teaching is a hindrance to quality instruction," and the use of ICT for teaching was identified as "the second highest area of professional development that teachers (18\%) report a high need for." Despite the identified need to provide teachers with ICT training, the results of the 2nd Survey of Schools conducted by the European Commission that were published in 2019 [4] showed that "more than 6 out of 10 European students are taught by teachers that engage in professional development activities about ICT in their own time" as "teacher training in ICT is rarely compulsory." Responses to the COVID-19 pandemic have increased the use of digital technology for teaching and learning; and are likely to increase the ICT professional development opportunities for teachers.

\subsection{Measuring the digitalization of education}

The European Framework for Digitally-Competent Educational Organisations (DigCompOrg) is a framework for promoting digital-age learning [5]. The framework was developed to guide processes of self-reflection and self-assessment for educational organizations as they work to integrate and deploy digital learning technologies. SELFIE (Self-reflection on Effective Learning by Fostering the use of Innovative Educational Technologies) [6] is an online self-reflection tool for schools based on DigCompOrg that works to highlight what is working well, where improvement is needed and what the priorities should be. SELFIE is a useful tool for capturing a 
snapshot of teacher perceptions at a specific moment that can later be used to gauge progress made toward developing digital learning competences.

\subsection{Emergency remote teaching}

Hodges et al. (2020) [1] define the term emergency remote teaching (ERT) as an alternate instructional delivery mode due to crisis circumstances. The primary objective is not to re-create a robust educational ecosystem but rather to provide full remote teaching solutions for instruction that are quick to set up. In other words, ERT "involves the use of fully remote teaching solutions for instruction or education that would otherwise be delivered face-to-face or as blended or hybrid courses and that will return to that format once the crisis or emergency has abated." In such crisis situations, despite the good intentions of educational centres and their teachers, reflective learning design [7] processes are hindered. What we know from research is that effective learning design should involve a careful analysis of the particular needs of students at the different educational levels and of other factors and concerns in their contexts [8]. The conclusions of this analysis phase inform later decisions in the design of (digital) distance teaching and learning. Without such an analysis, critical decisions are often pushed to the periphery. For example, decisions about what specific problems to tackle (e.g. those related to inclusion as "around one fifth of people in Spain are not yet online and close to half of them still lack basic digital skills" [10]), and about what skills [7] and supports are needed by teachers may not be adequately taken into consideration.

\section{Educational response to COVID-19 in Spain}

The COVID-19 outbreak resulted in brick-and-mortar Spanish educational centres (all levels) cancelling face-to-face teaching around mid-March 2020. The exact date depended on the particular region, but there were only a few days of difference (e.g. March 11 in Madrid and La Rioja, March 13 in Catalonia, Canary Islands and the Basque Country). By March 15, the Spanish government had mandated that schools across Spain were no longer permitted to hold face-to-face lessons. The closure of classrooms was initially thought to be a short-term measure and only some areas, such as Madrid, shifted their educational activities online at this stage [10]. It was not until April 15, after the spring holidays, that the Spanish Ministry of Education and Vocational Training (MEFP) announced that educational activity would be maintained at a distance for the third trimester of the school year [11]. On April 24, the Official State

Newsletter (Boletin Oficial del Estado) from the Government of Spain mandated that educational activity would be maintained at a distance and the school year would not be extended beyond June [12].

From the onset, top-down efforts were made to ease the burden on students [12-14], support socially disadvantaged students [15-17], and make resources available to schools and teachers $[15,18-20]$. For example, efforts to support socially disadvantaged students included the launching of 5 hours a day of educational programming on major TV channels [15], facilitating Internet access by sending out $40 \mathrm{~Gb} / \mathrm{month}$ SIM cards to 
upper secondary and vocational training students in need [16], and distributing digital devices to students that needed them [17]. Examples of top-down support by MEFP for educators included the sharing of online platforms with materials for teachers to use $[15,18,20]$, the launching of a website dedicated to facilitating access to remote teaching resources [18], and the creation a YouTube channel with video tutorials for teachers to support their use of digital tools [19]. With these top-down directives documented in public records, it is important to note the experiences from a bottom-up perspective. Thus, to investigate potential advances made in the digitisation of education that could be carried beyond emergency remote teaching, we highlight teacher perspectives on what went well, what needs remained unaddressed, and where opportunities may lie moving forward. Such information can inform near future TEL research and interventions. Accordingly, our study compares the situations of teachers both before and during the pandemic with regard to the following research questions: RQ1. How do teachers feel about the support they have received in digitizing their practices? RQ1.1. What kind of support/guidance has been received? RQ1.2. What has been useful? RQ1.3. What has been the perceived impact? RQ2. What challenges have emerged out of having to shift teaching online?

\section{$4 \quad$ Methodology}

We conducted a survey research study [21] to capture a picture of the emergency educational response to COVID-19 in Spain from a population of teachers.

\subsection{Participants and Sample}

Participants were 67 teachers ( $73.1 \%$ female) from primary and secondary schools in Spain (92.5\% from Catalonia, 4.5\% from Aragon and 3\% from Extremadura). Almost half of the teachers were from public schools $(47.8 \%)$ and half from semi-private schools $(50.7 \%)$. Only one teacher reported being from a private school $(1.5 \%)$. In terms of teaching experience, $43.3 \%$ of participants had more than 20 years of experience, $26.8 \%$ between 10 to 20 years, and $29.9 \%$ ten years or less of experience. The age distribution of participants was $1.5 \%$ under 25 years old; $11.9 \%$ from 25 to 29 years old; $10.4 \%$ from 30 to 39 years old; $34.3 \%$ from 40 to 49 years old; $31.3 \%$ from 50 to 59 years old; and $10.4 \%$ more than 60 years old. Table 1 presents participant characteristics regarding educational level taught (41.8\% from Primary Education and 58.2\% from Secondary Education); their approach in using digital technologies, from early adopters $(23.9 \%)$ to laggards (6\%); the percentage of teaching time devoted in class to using digital technologies in the three months before the closure of schools (results show balanced percentages); and the socio-economic aspects of their students. In addition, $92.5 \%$ of the teachers stated that there is an ICT coordinator in their school. 
Table 1. Participants' characteristics (f: frequency; yo: years old).

\begin{tabular}{|c|c|c|c|c|}
\hline \multicolumn{3}{|l|}{ Item } & \multirow{2}{*}{$\frac{f}{28}$} & \multirow{2}{*}{$\frac{\%}{41.8}$} \\
\hline \multirow{4}{*}{$\begin{array}{l}\text { Educational } \\
\text { level }\end{array}$} & \multicolumn{2}{|c|}{ Primary Education (6-12yo) } & & \\
\hline & & Secondary Education (13-16 yo) & 21 & 31.3 \\
\hline & Secondary & Upper Secondary General Education (17-18 yo) & 7 & 10.4 \\
\hline & & Upper Secondary Vocational Education ( $>17$ yo) & 11 & 16.4 \\
\hline \multirow{4}{*}{$\begin{array}{l}\text { Approach in } \\
\text { using digital } \\
\text { technologies }\end{array}$} & \multirow{2}{*}{\multicolumn{2}{|c|}{$\begin{array}{l}\text { I tend to use digital technologies after the majority of my colleagues. } \\
\text { I tend to use digital technologies at the pace of the majority of my } \\
\text { colleagues. }\end{array}$}} & 4 & 6 \\
\hline & & & 30 & 44.8 \\
\hline & \multicolumn{2}{|c|}{ I tend to be an early adopter where I see clear benefits. } & 17 & 25.4 \\
\hline & \multicolumn{2}{|c|}{ I am usually among the innovators who try out new technologies. } & 16 & 23.9 \\
\hline \multirow{5}{*}{\multicolumn{2}{|c|}{$\begin{array}{l}\text { Percentage of teaching time using } \\
\text { digital technologies in class in the } \\
3 \text { months before the schools close }\end{array}$}} & $0-10 \%$ & 7 & 10.4 \\
\hline & & $11-25 \%$ & 16 & 23.9 \\
\hline & & $26-50 \%$ & 20 & 29.9 \\
\hline & & $51-75 \%$ & 10 & 14.9 \\
\hline & & $76-100 \%$ & 14 & 20.9 \\
\hline \multirow{5}{*}{\multicolumn{2}{|c|}{$\begin{array}{l}\text { Percentage of students in the } \\
\text { school coming from economically } \\
\text { disadvantaged homes }\end{array}$}} & Fewer than $10 \%$ & 37 & 55.2 \\
\hline & & $10-25 \%$ & 17 & 25.4 \\
\hline & & $26-50 \%$ & 6 & 9 \\
\hline & & Above $50 \%$ & 3 & 4.5 \\
\hline & & I don't know & 4 & 6 \\
\hline
\end{tabular}

\subsection{Online Questionnaire}

We conducted a survey study using an online questionnaire. The instrument was adapted from the SELFIE tool [6] introduced in Section 2.1. Table 2 shows the questions used and their corresponding items/codes in SELFIE. In order to study the situations both before and during the pandemic, participants were able to mark two responses to each survey item considering both timeframes ("During the previous year before schools were forced to close" and "During the emergency remote teaching situation"). Most questions were answered using a five-point Likert scale. Questions regarding RQ1.1 (Q1a-d) used an agreement scale, questions concerning RQ1.2 (Q2a-f) used a usefulness scale, and questions with respect to RQ1.3 (Q3a-d) used a confidence scale. Moreover, a final question (Q4) connected with RQ2, asked participants to mark all of the negative factors that affect their teaching and learning with digital technologies. An additional open question was formulated by the authors asking whether teachers had considered different teaching strategies that could be more inclusive with students who were in difficult situations during the outbreak. 
Table 2. Questionnaire adapted from SELFIE [6].

\begin{tabular}{|c|c|c|}
\hline $\mathbf{Q}$ & $\begin{array}{l}\text { SELFIE } \\
\text { Item (Code) }\end{array}$ & Question \\
\hline Q1a & CPD needs (C1) & $\begin{array}{l}\text { Our school leaders discuss with us our Continuing Professional } \\
\text { Development (CPD) needs for teaching with digital tech. }\end{array}$ \\
\hline Q1b & $\begin{array}{l}\text { Participation in CPD } \\
\text { (C2) }\end{array}$ & $\begin{array}{l}\text { I have opportunities to participate in CPD for teaching and learn- } \\
\text { ing with digital technologies. }\end{array}$ \\
\hline Q1c & $\begin{array}{l}\text { Sharing experiences } \\
\text { (C3) }\end{array}$ & $\begin{array}{l}\text { Our school leaders support us to share experiences within school } \\
\text { about teaching with digital technologies. }\end{array}$ \\
\hline Q1d & $\begin{array}{l}\text { Digital assessment } \\
\text { (E1) }\end{array}$ & $\begin{array}{l}\text { Our school leaders support me in using digital technologies for } \\
\text { assessment. }\end{array}$ \\
\hline Q2a & $\begin{array}{l}\text { Online professional } \\
\text { learning }\end{array}$ & Online courses, webinars or online conferences. \\
\hline Q2b & $\begin{array}{l}\text { Learning through col- } \\
\text { laboration }\end{array}$ & $\begin{array}{l}\text { Learning from other teachers within your school through online } \\
\text { or offline collaboration. }\end{array}$ \\
\hline Q2c & $\begin{array}{l}\text { Learning through } \\
\text { professional networks }\end{array}$ & $\begin{array}{l}\text { Learning from other teachers through online teachers' networks } \\
\text { or communities of practice (such as eTwinning). }\end{array}$ \\
\hline Q2d & $\begin{array}{l}\text { In-house } \\
\text { mentoring /coaching }\end{array}$ & $\begin{array}{l}\text { In-house mentoring or coaching, as part of a formal school ar- } \\
\text { rangement. }\end{array}$ \\
\hline Q2e & $\begin{array}{l}\text { Other in-house train- } \\
\text { ing }\end{array}$ & $\begin{array}{l}\text { Other in-house training sessions organised by the school (for } \\
\text { instance workshops by the ICT Coordinator or observing col- } \\
\text { leagues teaching). }\end{array}$ \\
\hline Q2f & $\begin{array}{l}\text { Accredited } \\
\text { programmes }\end{array}$ & $\begin{array}{l}\text { Accredited programmes (for instance short accredited courses, } \\
\text { degree programmes). }\end{array}$ \\
\hline Q3a & $\begin{array}{l}\text { Preparing lessons } \\
\text { Class }\end{array}$ & $\begin{array}{l}\text { Preparing lessons by editing or creating a variety of digital re- } \\
\text { sources (for instance slide show, images, audio or video). }\end{array}$ \\
\hline Q3b & Class teaching & $\begin{array}{l}\text { Class teaching using a variety of devices (such as interactive } \\
\text { whiteboards, video projectors) and resources (for instance } \\
\text { online quizzes, mind maps, simulations). }\end{array}$ \\
\hline Q3c & Feedback and support & $\begin{array}{l}\text { Assessing or providing personal feedback and support to stu- } \\
\text { dents. }\end{array}$ \\
\hline Q3d & Communication & Communicating with students and parents. \\
\hline Q4 & $\begin{array}{l}\text { Negative factors for } \\
\text { technology use }\end{array}$ & $\begin{array}{l}\text { Is teaching and learning with digital } \\
\text { technologies in your (school/at home) negatively affected by } \\
\text { the following factors? }\end{array}$ \\
\hline
\end{tabular}

${ }^{1}$ See list of factors in Figure 4.

\subsection{Procedure and Analysis}

Both Catalan and Spanish versions of SELFIE were offered to participants dependent on the region they taught in. The Spanish version was an official translation of the tool. The Catalan version was translated by the authors. The survey was administered online by sharing links to the questionnaire on teacher WhatsApp groups and by emailing teachers directly. Due to the emergency situation, it was anticipated that response rates would be low. To maximize response rates, personal recruitment approaches were prioritized as such approaches have been shown to increase response rates [22]. For example, the questionnaire was disseminated to school communities through existing contacts following a collaborative rather than top-down approach. The questionnaire was 
open for 5 days, from April 20 to 24 . The response rate was 30\% (74 total responses out of 241 total clicks to the online link). Statistical tests were used to analyse the collected data. Specifically, we used nonparametric statistical tests for comparing groupings of responses (before the emergency versus during the emergency; public versus semi-private school teachers; primary versus secondary school teachers).

\section{$5 \quad$ Results}

\subsection{What Kind of Support Has Been Received?}

Figure 1 shows a comparison of the situations before and during the COVID-19 emergency related to training opportunities and support from school leaders (Q1a-d). Results show that for primary education teachers, their inclusion by school leaders in detecting continuing professional development (CPD) needs increased significantly during the emergency when compared to the period prior to the forced closing of schools ((b): $M=3.43, S E=0.22$; (d): $M=3.89, S E=0.16$; Wilcoxon Test, $p=0.019$ ). During the pandemic, there was a significant increase in opportunities for all teachers to participate in CPD ((b): $M=3.81, S E=0.14$; (d): $M=4.0, S E=0.13$; Wilcoxon Test, $p=0.024)$. Moreover, school leaders provided a significantly higher level of support to all teachers with regard to the use of digital technologies for assessment during the emergency situation considering all educational levels ((b): $M=3.35, S E=0.17$; (d): $M=3.6, S E=0.17$; Wilcoxon Test, $p=0.006$ ) and in primary schools ((b): $M=3.44, S E=0.0 .27$; (d): $M=3.85$, $S E=0.24$; Wilcoxon Test, $p=0.008$ ). Nevertheless, results suggest that school leaders' support of teachers in sharing their experiences within the school did not change during the COVID-19 situation (since no significant differences were found comparing both timeframes). Lastly, no statistically significant differences were found regarding the above items related to training opportunities and support from school leaders based on the type of school (public versus semi-private).

The second group of questions (Q2a-f) asked participants to report the usefulness of several CPD modalities using a Likert scale (see Figure 2). One of the options provided was the response "I did not participate." From the selections of this option, we determined participation rates in the listed CPD modalities for both before and during the COVID-19 pandemic. Learning through collaboration (i.e. learning from other teachers within the same school through online or offline collaboration) was the CPD activity with the highest participation rate. Yet, the percentage of teachers not participating in learning through collaboration was slightly lower during the emergency $(10.4 \%)$ than before (11.9\%). Before the emergency, $89.6 \%$ of teachers learned through collaboration whereas $88.1 \%$ did so during the emergency. Online professional learning (attending online courses, webinars or online conferences) was the CPD activity with the second highest rate of participation during the COVID-19 emergency, and was the only CPD activity that had a higher rate of participation during the emergency situation (77.6\% before the emergency, $83.5 \%$ during the emergency). Training sessions organized by a teacher's school had a participation rate of $75.6 \%$ before the emergency and $73.1 \%$ during it. In house mentoring or coaching and learning through professional networks had the lowest participation rates. 


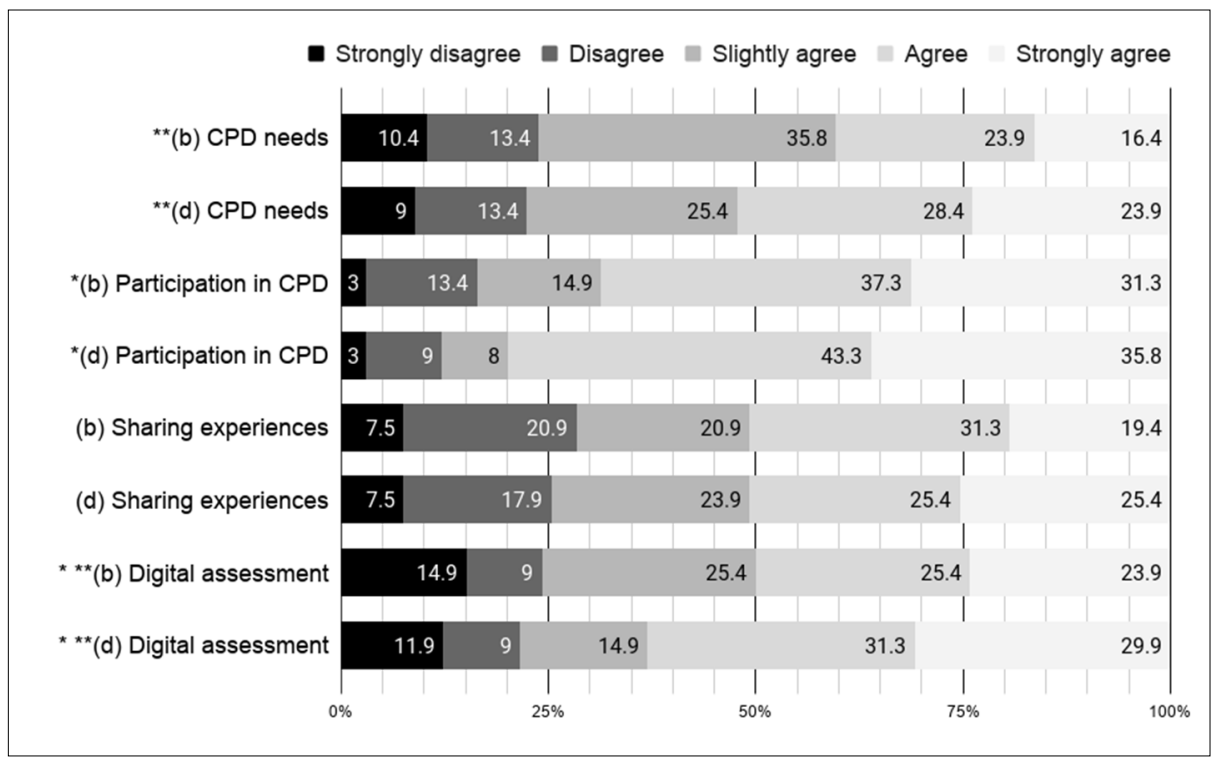

Fig. 1. Schools' support to the continuing professional development (CPD) of teachers ( $N=67)$. (b) before the emergency, (d) during the emergency remote teaching. *significant differences found between b/d items' groups considering all levels ** considering Primary teachers.

\subsection{What Has Been Useful?}

Figure 2 shows teacher ratings of usefulness for several CPD modalities (Q2a-f). The usefulness ratings of all types of CPD activities were slightly higher during the COVID19 emergency than before it. As shown in Figure 2, learning through collaboration received the highest usefulness ratings. However, the increase for this modality was not statistically significant. Usefulness ratings for online professional learning were significantly higher during the pandemic compared to before it ((b): $M=3.98 ; S E=0.12$; (d): $M=4.20 ; S E=0.13$; Wilcoxon Test, $p=0.005)$. Usefulness ratings for in-house training sessions organised by the school (e.g. workshops by the ICT Coordinator or observing colleagues teaching) were significantly higher during the pandemic compared to before it for Primary school teachers ((b): $M=3.81, S E=0.16$; (d): $M=4.05 ; S E=0.17$; Wilcoxon Test, $p=0.025$ ) but not for Secondary school teachers. Likewise, usefulness ratings for accredited programmes were significantly higher during the pandemic compared for Primary school teachers ((b): $M=4.11, S E=0.18$; (d): $M=4.32 ; S E=0.18$; Wilcoxon Test, $p=0.046$ ) but not for Secondary school teachers. For Secondary school teachers, usefulness ratings for in-house mentoring or coaching were significantly higher during the pandemic in comparison to before it ((b): $M=4.05, S E=0.21 ;(d): M=4.30 ; S E=0.20$; Wilcoxon Test, $p=0.025$ ). 


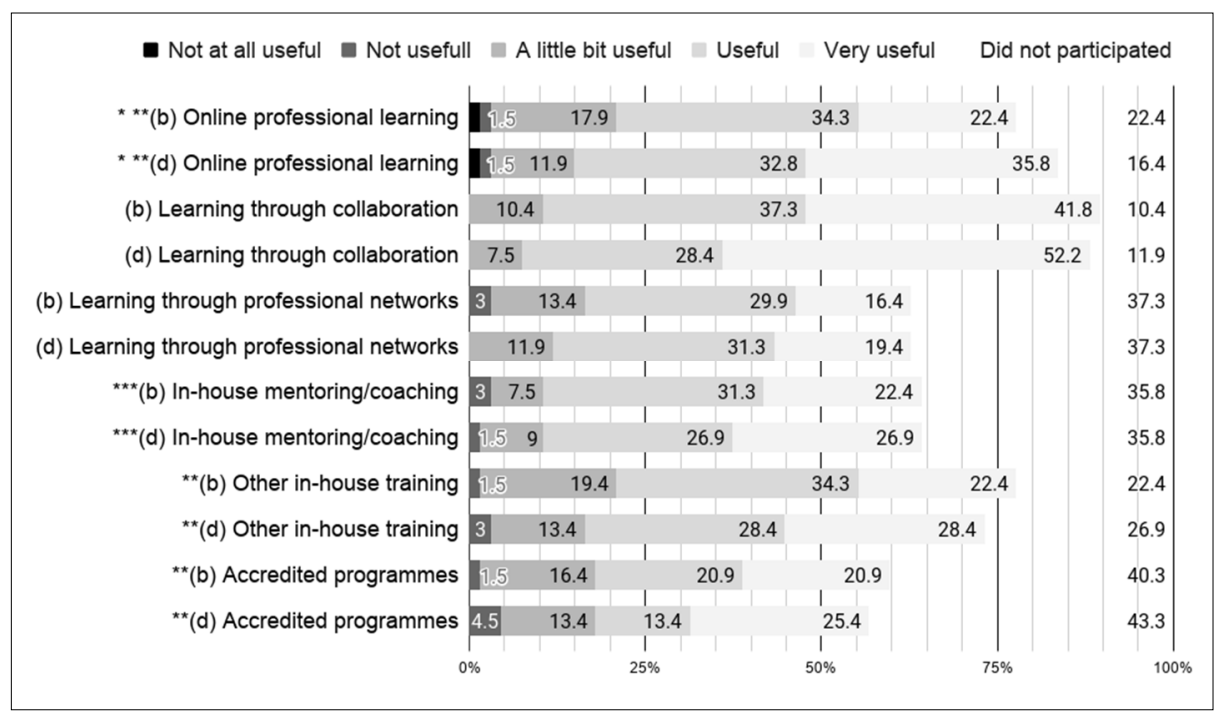

Fig. 2. Teachers' perspective about the usefulness of several CPD modalities $(N=67)$. (b) before the emergency, (d) during the emergency remote teaching. *significant differences found between b/d items' groups considering all educational levels, ** considering only Primary teachers, *** considering only Secondary teachers.

\subsection{What Has Been the Impact?}

Figure 3 presents a comparison of teacher confidence levels with regard to using digital technologies for the situations before and during the COVID-19 emergency (Q3a-d). The results show that, during the emergency, teachers had a significantly higher level of confidence in using a variety of devices (such as interactive whiteboards, video projectors) and resources (e.g. online quizzes, mind maps, simulations) than during the period prior to the emergency ((b): $M=3.59, S E=0.14$; (d): $M=3.77, S E=0.14$; Wilcoxon Test $p=0.005)$. Further, during the pandemic, teachers indicated having a significantly higher level of confidence in communicating with students and parents using digital devices ((b): $M=4.09, S E=0.12$; (d): $M=4.3, S E=0.11$; Wilcoxon Test $p=0.002$ ). Both primary and secondary levels presented statistically significant differences for the items above. However, teacher confidence in preparing lesson plans by editing or creating a variety of digital resources (e.g. slide show, images, audio or video) and providing personal feedback and support to students did not present any statistically significant differences compared to the situation before the COVID-19 emergency (neither when comparing all educational levels nor when focusing on primary or secondary in particular). 


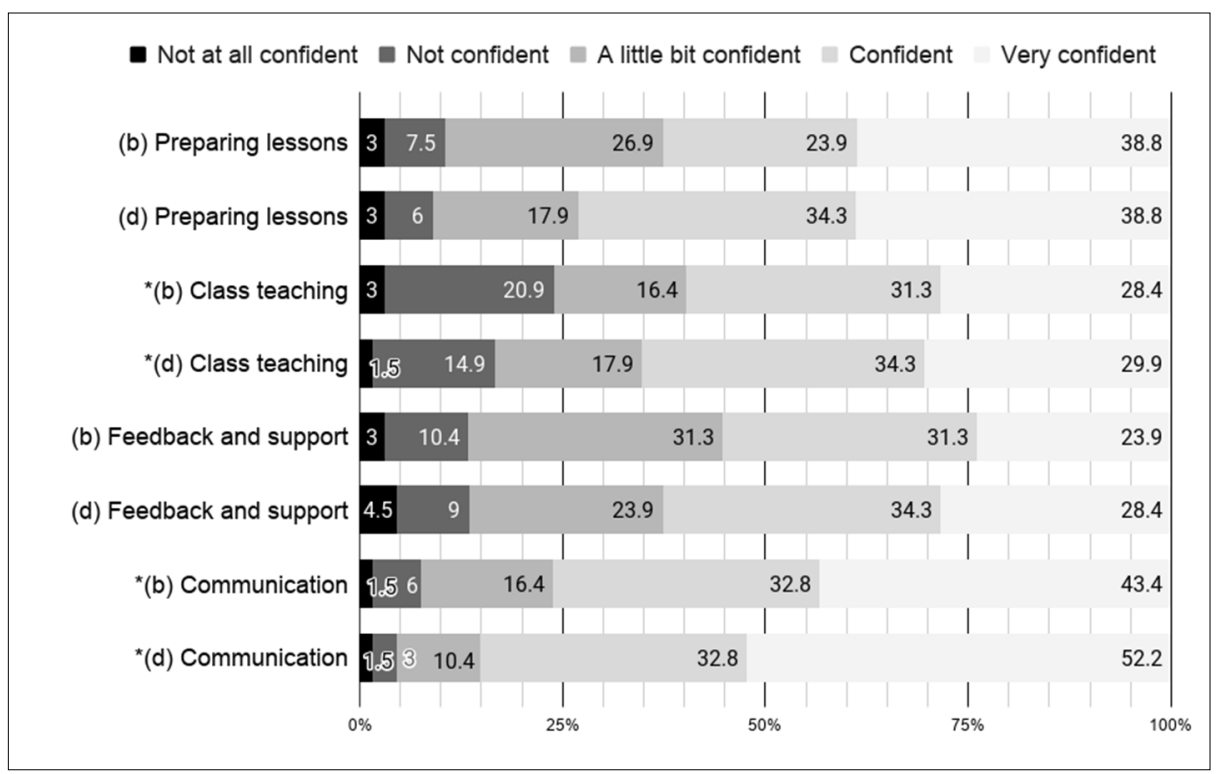

Fig. 3. Teachers' confidence in using digital technologies $(\mathrm{N}=67)$. (b) before the emergency, $(d)$ during the emergency remote teaching. *significant differences found between $b / d$ items' groups considering all educational levels

\subsection{What Challenges Have Teachers' Faced?}

Figure 4 shows a list of negative factors affecting teachers' use of digital technologies for teaching and learning. The factors are ordered by frequency levels (highest to lowest) based on the before COVID-19 situation responses (Q4). As many studies have reported [24][25], teachers cite lack of time as the main barrier hindering their adoption of digital technologies for teaching. Consistent with the literature, Figure 4 shows that lack of time was the most frequently marked negative factor for using technologies for teaching and learning before the emergency $(f=32)$. Other negative factors before the pandemic were insufficient access to digital equipment $(f=28)$, student difficulties accessing digital technologies at home $(f=23)$, low digital competences of teachers $(f=21)$, and lack of funding $(f=10)$.

During the pandemic, aspects related to inclusion and digital divides (i.e. student difficulties in accessing digital technologies and/or Internet at home; students' difficulties in having family support due to issues such as poverty and language) became the most frequently marked negative factors. Lack of time fell to the fifth position. Moreover, $78.1 \%$ of teachers stated that, during the emergency, they considered different teaching strategies that could be more inclusive of students who were in difficult situations. Other negative factors experienced during the outbreak were unreliable or slow Internet connections at teachers' homes $(f=22)$, lack of time $(f=19)$, insufficient access to digital equipment at home $(f=14)$ and limited or no technical support $(f=12)$. 


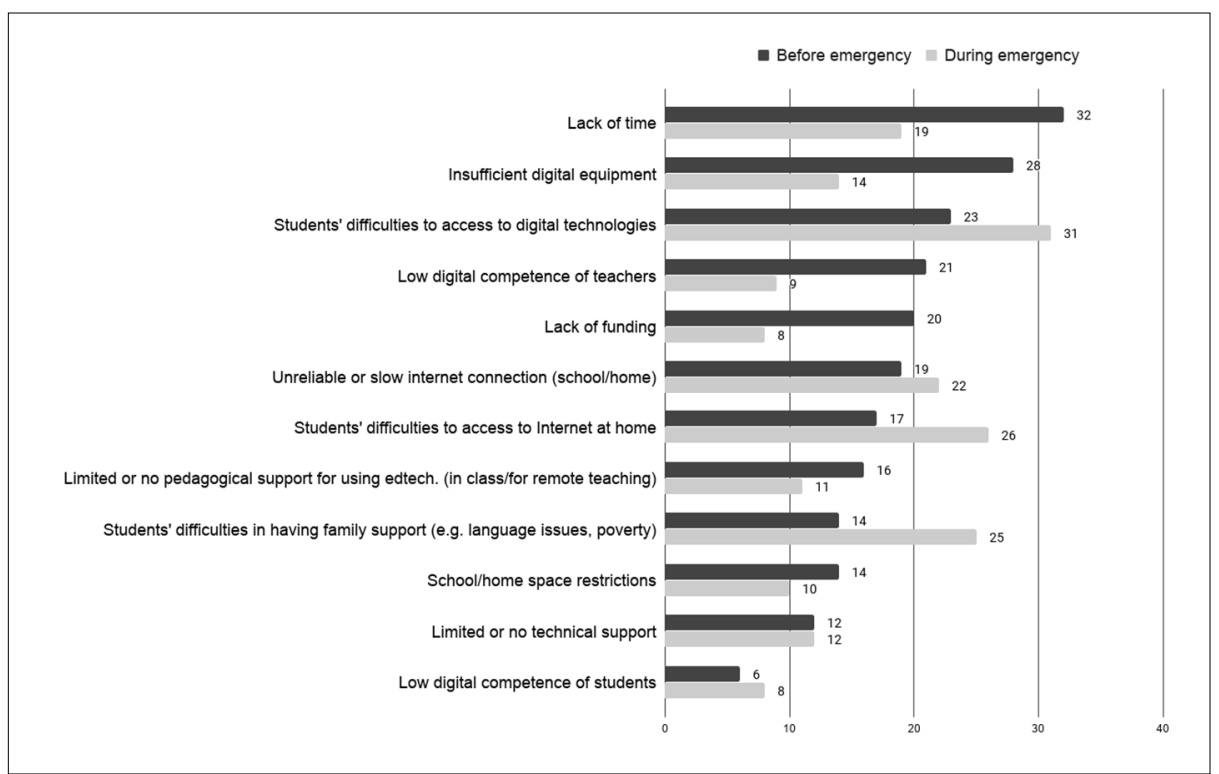

Fig. 4. Negative factors affecting the teaching and learning with digital technologies $(N=67)$; Results in frequencies.

\section{Discussion}

As top-down directives are documented in public records, it's important to also document the bottom-up experiences of those reacting to the messages (i.e. teachers) - in order to gauge what went well, what needs remained unaddressed, and where opportunities lie moving forward. The results suggest that efforts have fallen largely into "emergency remote teaching" with a lower emphasis on effectiveness (pedagogically) and more of an emphasis on communicating and meeting basic requirements. This is evidenced by the type of CPD and support offered to teachers (e.g. online learning vs. peer sharing of resources) and the fact that despite teachers increasing their remote teaching activities there was no change in teacher confidence levels regarding planning online lessons and delivering feedback to students online (e.g. critical pedagogical skills). Yet, for TEL researchers, some important advancements were realized such as increased opportunities for digital skills training, greater involvement of teachers in defining CPD needs, more support for digital assessments, greater confidence in device usage/technologies/resources for teaching and communication. The advancements are closely tied to the previously introduced priorities of the European Commission's Digital Action Plan and work to address some of the needs identified in the TALIS and 2nd Survey of Schools related to ICT training opportunities for teachers. In addition, top-down efforts by MEFP increased teaching resources available to teachers, resulted in bold initiatives to support socially disadvantaged students, and demonstrated flexibility in student evaluation and promotion requirements. This reflects a potential context change in the TEL domain, where the stakeholders (teachers, learners, educational managers, policy 
makers) may have more elaborated (but partial) knowledge and beliefs about the potential and limitations of technology, with implications in their participation in co-design methodologies and adoption studies.

The main limitations of our study relate to the survey research method followed and the generalizability of our findings. Despite using a validated questionnaire, the results may present an oversimplification of social reality and may be biased by respondents' lack of truth [26]. Moreover, some items from SELFIE may have been misinterpreted by participants. Specifically, the results related to CPD modality usefulness ratings and participation rates should be interpreted with caution. SELFIE instructs participants to only rate the usefulness for CPD activities that teachers had participated in, however, we cannot prove that teachers adhered to these instructions. Further, the generalizability of the results is affected by a limited sample size and by a possible lack of diversity among participants. The focus of the study was on teachers in Spain. Spain ranks 11th out of 28 EU Member States in the Digital Economy and Society Index (DESI) 2019 [9]. Thus, realities in other countries are likely to differ. Although the survey was publicly available for Spanish teachers in general, participants of the study were mostly $(92.5 \%)$ from Catalonia. Catalonia is an autonomous community in Spain granted certain rights to adapt parts of its competency curriculum (affecting the teaching practices related to digital skills and digitalization). Hence, the reality in other parts of Spain may differ.

Future investigations could include a more detailed analysis of the results based on participants' characteristics (e.g. level of experience, approach to the use of digital technologies or considering teachers' teaching time using technologies in class before the pandemic). Moreover, to develop a more complete picture of the educational implications resulting from the COVID-19 situation, we plan to do a post-emergency study collecting teachers' perspectives (through questionnaires and interviews). Specifically, we aim to investigate if there have been any long-term changes to teacher mindsets regarding the use of digital technologies for teaching and learning because of the rapid advancement of digital competences and technology in education.

\section{Conclusions}

The purpose of this study was to capture a snapshot of teachers' experiences in Spain during the emergency remote teaching caused by the COVID-19 crisis. We used the SELFIE tool to study from a bottom-up perspective, teacher perspectives on what had gone well, what needs remained unaddressed, and where opportunities may lie moving forward. On the one hand, the participation of teachers in decision-making regarding the identification of their training needs increased, as did their participation and ratings of usefulness for online professional learning. On the other hand, the emergency situation revealed factors affecting teachers' abilities to carry out online education, such as the digital divide among students and a lack of technical resources and technical support. Even in the early stages of emergency remote teaching from which our study was conducted, teachers gained a greater awareness of and confidence in using a wide variety of technologies and resources (e.g. especially those that support communication and 
assessment). This rapid advancement of digital competences and technology in education offers to bolster TEL research opportunities that relate to or build off of the emergency remote teaching experiences of teachers.

Acknowledgements. The authors would like to thank all the teachers who participated in the survey. This work has been partially funded by the EU Regional Development Fund, the National Research Agency of the Spanish Ministry of Science, Innovation and Universities and Erasmus+, under project grants TIN2017-85179-C3-3-R, 2019-1FI01-KA201-060881, 2019-1-ES01-KA201-065279. D. Hernández-Leo acknowledges the support by ICREA under the ICREA Academia programme.

\section{References}

1. Hodges, C., Moore, S., Lockee, B., Trust, T., Bond, A.: The Difference Between Emergency Remote Teaching and Online Learning (2020). Retrieved from https://er.educause.edu/articles/2020/3/the-difference-between-emergency-remote-teaching-and-online-learning

2. European Commission: Communication from the Commission to the European Parliament, the Council, the European Economic and Social Committee and the Committee of the Regions on the Digital Education Action Plan (2018). Retrieved from https://eur-lex.europa.eu/legal-content/EN/TXT/?uri=COM:2018:22:FIN

3. Schleicher, A.: Teaching and Learning International Survey TALIS 2018 Insights and Interpretations (2020). Retrieved from http://www.oecd.org/education/talis/TALIS2018_insights_and_interpretations.pdf

4. European Commission: 2nd Survey of Schools: ICT in Education (2019). Retrieved from https://ec.europa.eu/digital-single-market/en/news/2nd-survey-schools-ict-education

5. Kampylis, P., Punie, Y., Devine, J.: Promoting effective digital-age learning - A European framework for digitally-competent educational organisations. JRC Technical Reports (2015). https://doi.org/10.2791/54070

6. European Commission: Selfie Guide for School Coordinators (2018). https://ec.europa.eu/education/schools-go-digital_en

7. Mor, Y., Craft, B., Hernández-Leo, D.: Editorial: The art and science of learning design. Journal of Research in Learning Technologies 21 (2013) https://doi.org/10.3402/rlt.v21i0.22513

8. Asensio-Pérez, J. I., Dimitriadis, Y., Pozzi, F., Hernández-Leo, D., Prieto, L. P., Persico, D., Villagrá-Sobrino, S. L.: Towards teaching as design: Exploring the interplay between fulllifecycle learning design tooling and Teacher Professional Development. Computers \& Education, 114, 92-116 (2017)

9. European Commission: The Digital Economy and Society Index (DESI) (2019). Retrieved from https://ec.europa.eu/digital-single-market/en/desi

10. Ferrero, B.: Coronavirus: Los alumnos arrancan sus clases 'online' en el caos de la reclusión. El País (2020, March 17). Retrieved from https://elpais.com/espana/madrid/2020-03-16/losalumnos-arrancan-sus-clases-online-en-el-caos-de-la-reclusion.html

11. La Moncloa: Educación y Formación Profesional y las comunidades autónomas acuerdan mantener la duración del curso escolar hasta junio (2020, April 15). Retrieved from https://www.lamoncloa.gob.es/serviciosdeprensa/notasprensa/educacion/paginas/2020/140420-educacion.aspx 
12. Ministerio de Educación y Formación Profesional (MEFP): Orden EFP/365/2020, de 22 de abril, por la que se establecen el marco y las directrices de actuación para el tercer trimestre del curso 2019-2020 y el inicio del curso 2020-2021, ante la situación de crisis ocasionada por el COVID-19. Boletín Oficial del Estado, 4609, April 24 (2020). Retrieved from https://www.boe.es/boe/dias/2020/04/24/pdfs/BOE-A-2020-4609.pdf

13. La Moncloa: Celaá: Hemos tomado medidas para que todos los alumnos puedan terminar el curso sin verse perjudicados por la suspensión de las clases presenciales, April 26 (2020). Retrieved from https://www.lamoncloa.gob.es/serviciosdeprensa/notasprensa/educacion/Paginas/2020/120320-celaa.aspx

14. Ministerio de Educación y Formación Profesional (MEFP): El Ministerio de Educación y Formación Profesional y el de Universidades acuerdan cambios en el calendario y en las pruebas de acceso a la Universidad (EBAU), March 15 (2020). Retrieved from https://www.educacionyfp.gob.es/prensa/actualidad/2020/03/20200325-sectorial.html

15. Ministerio de Educación y Formación Profesional (MEFP): El Ministerio de Educación y FP y RTVE lanzan 'Aprendemos en casa' para facilitar el aprendizaje de todo el alumnado durante la suspensión de clases presenciales, March 21 (2020). Retrieved from https://www.educacionyfp.gob.es/prensa/actualidad/2020/03/20200321-mefprtve.html

16. Ministerio de Educación y Formación Profesional (MEFP): El Ministerio de Educación y Formación Profesional, Telefónica, Cisco e IBM facilitan la continuidad educativa de los estudiantes de Bachillerato y FP, March 30 (2020). Retrieved from https://www.educacionyfp.gob.es/prensa/actualidad/2020/03/20200330-tarjetasdatos.html

17. Departament d'Educació: Educació comença el procés de repartiment de 22.000 dispositius amb connectivitat a alumnes que no en disposen per seguir el curs des de casa, April 14 (2020). Retrieved from http://ensenyament.gencat.cat/ca/inici/nota-premsa/?id=384760

18. La Moncloa: Educación y Formación Profesional pone a disposición de la comunidad educativa una web con contenido pedagógico para trabajar en un entorno virtual, March 23 (2020). Retrieved from https://www.lamoncloa.gob.es/serviciosdeprensa/notasprensa/educacion/Paginas/2020/230320-web-educacion.aspx

19. Departament d'Educació: Educació crea 615 entorns virtuals d'aprenentatge Moodle perquè tots els centres puguin dur a terme la docència en línea, April 10 (2020). Retrieved from http://ensenyament.gencat.cat/ca/inici/nota-premsa/?id=384716

20. Departament d'Educació: Educació ofereix més de 100 models de propostes didàctiques als centres per treballar durant el $3 \mathrm{r}$ trimestre, April 9 (2020). Retrieved from http://ensenyament.gencat.cat $/ \mathrm{ca} / \mathrm{inici} /$ nota-premsa/?id $=384642$

21. Krosnick, J. A.: Survey Research. Annual Review of Psychology, 50, 537-567 (1999)

22. Edwards, P., Roberts, I., Clarke, M., DiGuiseppi, C., Pratap, S., Wentz, I. K.: Increasing response rates to postal questionnaires: systematic review. British Journal of Medicine 324: $1183(2002)$

23. Morse, J.M., Field, P. A.: Nursing Research: The Application of Qualitative Approaches. London, Chapman and Hall (1996)

24. Dagnino, F. M., Dimitriadis, Y. A., Asensio-Pérez, J. I., Pozzi, F., Rubia-Avi, B.: Exploring teachers' needs and the existing barriers to the adoption of Learning Design methods and tools: A literature survey. British Journal of Educational Technol., 49 (6), 998-1013 (2018)

25. Lewin, C., Cranmer, S., McNicol, S.: Developing digital pedagogy through learning design: An activity theory perspective. British Journal of Educational Technology, 49 (6), 11311144 (2018). https://doi.org/10.1111/bjet.12705

26. Hall, B.: Breaking the monopoly of knowledge: research methods, participation and development. In: Hall B. Gillette A, Tandon R. eds. Creating Knowledge: A Monopoly? Toronto: International Council for Adult Education, 1-13 (1982) 